JKKP : Jurnal Kesejahteraan Keluarga dan Pendidikan

http://doi.org/10.21009/JKKP

DOI: doi.org/10.21009/JKKP.042.09

E-ISSN : 2597-4521

\title{
LITERASI ASESMEN IPA
}

\author{
Rizkia Suciati1 ${ }^{1, a)}$, Gufron Amirullah,b) \\ Email : a)riris9186@gmail.com, ${ }^{\text {b) }}$ gufron@ymail.com \\ 1,2 Program Studi Pendidikan Biologi \\ Universitas Muhammadiyah Prof. Dr. Hamka
}

\begin{abstract}
Abstrak
Penelitian bertujuan mengetahui literasi asesmen dari guru-guru sekolah dasar di Bengkulu. Survei dilakukan terhadap guru sekolah dasar $(n=28)$ yang berasal dari 22 sekolah dasar dari 5 kecamatan se-kota bengkulu. Responden diminta melengkapi 4 pertanyaan tertutup dan 5 pertanyaan terbuka berkenaan dengan tingkat literasi asesmen, tujuan utama dari asesmen dan pemanfaatan berbagai teknik asesmen, kebutuhan akan pelatihan lanjutan dan cara-cara yang disarankannya untuk meningkatkan literasi asesmen di perguruan tinggi dan pada praktek keguruan (PPL).

Sebagian besar responden menilai tingkat kemampuan asesmen mereka relatif baik, meskipun hal itu bertolak belakang dengan pendapat mereka tentang tujuan asesmen. Tujuan sumatif masih mendominasi sebagai tujuan asesmen dalam pembelajaran, sedikit yang berpendapat asesmen dilakukan untuk keperluan formatif (pengembangan) dan diagnostik. Mereka lebih menyukai menggunakan teknik asesmen komunikasi personal dan tes pilihan (responden terbatas), namun bila ada pelatihan teknik asesmen di masa mendatang mereka memilih teknik asesmen observasi. Perguruan tinggi dapat berperan dalam pengembangan literasi asesmen calon guru dan guru, termasuk melalui kerja sama dengan Dinas Pendidikan.
\end{abstract}

Kata kunci: asesmen, literasi IPA, SD

\section{Ass essment Literasi of Science on Elementary School Teachers in Bengkulu}

\begin{abstract}
Descriptive study about assessment literacy of primary school teachers conducted to determine the extent to which literacy assessment of elementary school teachers in Bengkulu. Surveys carried out on primary school teachers $(n=28)$ derived from 22 primary schools from five districts as the city of Bengkulu. Respondents were asked to complete the four questions are closed and five open questions regarding the level of assessment literacy, main purposes of assessment and use of various assessment techniques, the need for further training and recommends ways to improve the literacy assessment in higher education and on teaching practices (PPL). The majority of respondents rate their skill level assessment is relatively good, although it was contrary to their opinions about the purpose of assessment. Summative purpose still dominates as the purpose of assessment in learning, little is done for purposes of the opinion formative assessment (development) and diagnostics. They prefer using the technique of personal communication assessment and selection tests (respondents limited), but if there are training techniques in future assessments of their choosing assessment techniques of observation. Universities can play a role in the development of assessment
\end{abstract}


literacy of teachers and teacher candidates, including through cooperation with the Department of Education.

Keywords: assessment; elementary school teachers in Bengkulu

\section{PENDAHULUAN}

Asesmen adalah pengumpulan bukti yang diilakukan secara sengaja, sistematis, dan berkelanjutan serta digunakan untuk menilai kompetensi siswa. Asesmen memberikan umpan balik mengenai kemajuan belajar siswa untuk siswa, orang tua, dan guru. Asesmen juga membantu guru untuk membuat keputusan-keputusan mengenai kebutuhan siswa, dan pedoman perencanaan program pembelajaran. Di samping hal tersebut, asesmen harus menjadi bagian yang tidak terpisah dari program pembelajaran. Guru perlu memperhatikan bukti-bukti belajar dari kegiatan sehari-hari yang dilakukan para siswa. Bukti-bukti ini akan menunjukkan apa yang sudah diketahui siswa, dan apa yang masih perlu mereka ketahui. (Anonim, 2010).

Literasi asesmen (penilaian) didefinisikan sebagai suatu pemahaman terhadap prinsip-prinsip asesmen. Guru yang memiliki literasi asesmen yang mantap akan berada pada posisi baik untuk mengintegrasikan asesmen ke dalam pembelajaran, karena mereka menggunakan bentuk-bentuk yang tepat, sesuai dengan pembelajaran (Volante \& Fazio, 2007).

\section{HAKIK AT PEMBELAJ AR AN IPA}

Pernyataan mengenai "S cience is both a body of knowledge and a process", diartikan oleh Cain \& Evans (...) bahwa IPA adalah kumpulan dari pengetahuan dan bagaimana proses untuk mendapatkan pengetahuan tersebut. IPA atau sains mengandung empat hal, yaitu: konten atau produk, proses atau metode, sikap dan teknologi (dalam Rustaman dkk, 2005).

Interaksi di antara proses, sikap dan produk dalam sains sangatlah berkaitan. Proses yang disertai sikap ilmiah akan menghasilkan produk yang ilmiah, dan produk ilmiah yang dihasilkan tentunya akan menjadi dasar bagi proses ilmiah berikutnya untuk menghasilkan produk ilmiah yang baru.

Namun pada kenyataannya, pembelajaran IPA di sekolah dasar belum melibatkan konsepkonsep ilmiah, dan terbatas pada pengungkapan gejala-gejala alam berupa fakta, padahal pembelajaran IPA sebaiknya dilaksanakan secara inkuiri ilmiah (scientific inquiry) untuk menumbuhkan kemampuan berpikir, bekerja dan bersikap ilmiah serta mengkomunikasikannya sebagai aspek penting kecakapan hidup dengan menekankan pada pemberian pengalaman belajar secara langsung melalui penggunaan dan pengembangan keterampilan proses dan sikap ilmiah (Depdiknas, 2006).

Selaras dengan pernyataan di atas, National Science Standards (NRC, 1996) menyarankan bahwa para siswa perlu belajar untuk :

1. Mengidentifikasi pertanyaan-pertanyaan dan konsep-konsep yang mengarah pada penyelidikan ilmiah;

2. Mendisain dan melakukan penyelidikan ilmiah;

3. Menggunakan teknologi dan matematika untuk meningkatkan penelitian dan komunikasi;

4. Merumuskan dan meninjau kembali penjelasan-penjelasan dan model-model ilmiah menggunakan logika dan bukti;

5. Mengenali dan meneliti penjelasan dan model-model alternatif; dan

6. Mengkomunikasikan dan mempertahankan suatu argumentasi ilmiah.

7. (dalam akbar \& rustaman, 2009). 


\section{MODEL-MODEL ASE SME N IPA}

Penilaian proses dan hasil belajar IPA menuntut teknik dan cara-cara penilaian yang lebih komprehensif. Di samping aspek hasil belajar yang dinilai harus menyeluruh yaitu aspek kognitif, afektif, dan psikomotorik, teknik penilaian dan instrumen penilaian seyogianya lebih bervariasi. Stiggins (1994) mengemukakan bahwa hasil belajar dapat dibedakan menjadi pengetahuan (knowledge), penalaran (reasoning), keterampilan (skills), hasil karya (product), dan afektif (dalam Akbar \& Rustaman, 2009).

Puskur (2007) mengatakan bahwa hasil belajar dapat dideteksi melalui beberapa cara atau teknik, seperti: pilihan atau respons terbatas (selected response), asesmen esai (essay assessment), asesmen kinerja (performance assessment), dan komunikasi personal (personal communication). Rustaman (2006) juga menyarankan, penilaian IPA hendaknya mengukur pengetahuan dan konsep, keterampilan proses sains (KPS), dan penalaran tingkat tinggi (berpikir kritis, logis, kreatif) serta menggunakan penilaian portofolio dan asesmen kinerja untuk KPS dan kemampuan kerja ilmiah selama pembelajaran IPA.

Asesmen dalam IPA berfungsi sebagai alat untuk merencanakan, pedoman dan memperkaya pembelajaran IPA di kelas; alat komunikasi dengan murid, administrator dan orang tua murid tentang pentingnya IPA; alat untuk memonitor hasil belajar IPA dan perbaikan pembelajaran; serta alat untuk memperbaiki kurikulum dan pengajaran IPA (Iskandar dan Hidayat, 1997). Dengan demikian hasil penilaian tampak memiliki fungsi yang sangat luas, tidak semata-mata mengukur keberhasilan siswa dalam belajar.

Asesmen diagnostik digunakan untuk menentukan pengetahuan dan pemahaman apa yang dibawa seorang siswa untuk memasuki topik tertentu. Hal yang paling penting dalam asesmen diagnostik adalah para guru harus jelas tentang apa yang mereka ingin lakukan dalam pembelajaran sains dan mengetahui bagaimana kualitas yang mereka harapkan untuk dapat dimiliki para siswa (Akbar \& Rustaman, 2009). Sementara itu, untuk meningkatkan proses pembelajaran guru biasanya memanfaatkan hasil asesmen formatif. Ruiz-Primo \& Furtak (2007) mengatakan bahwa asesmen formatif dapat meliputi pengumpulan, penafsiran, dan tindakan terhadap informasi tentang pembelajaran siswa sehingga mungkin saja diperbaiki. Informasi yang diperoleh melalui asesmen formatif harus digunakan untuk memodifikasi aktivitas pembelajaran untuk mengurangi kesenjangan antara kinerja siswa yang diinginkan dan kinerja siswa yang teramati. Penggunaan asesmen formatif informal terbukti dapat meningkatkan performan siswa dalam embedded assessment. Berbeda dengan asesmen formatif formal, asesmen formatif informal lebih improvisasional dan dapat berlangsung di dalam setiap interaksi siswa-guru pada level kelas, kelompok kecil, atau secara berhadap-hadapan. Informasi yang terkumpul bersifat sementara (dalam Akbar \& Rustaman, 2009).

Yang terakhir adalah penggunaan asesmen tradisional, yaitu asesmen sumatif yang terdiri atas tes-tes pada akhir masa pembelajaran. Istilah itu perlu diperluas dengan memasukkan ke dalamnya berbagai pertimbangan atas dasar bukti-bukti yang telah dipelajari siswa setelah belajar topik tertentu. Perkembangan siswa tersedia manakala para guru mengkombinasikan data pretest (pekerjaan siswa sebelum topik dipelajari), "asesmen melekat" (rekaman aktivitas kelas pada saat topik sedang dipelajari), dan posttes (menggambar, uraian-uraian, atau menjawab pertanyaanpertanyaan yang dilakukan setelah suatu topik dipelajari). Secara bersama-sama, informasi ini menyediakan suatu asesmen sumatif (Akbar \& Rustaman, 2009).

\section{METODE PENELITIAN}

Penelitian ini dilakukan di 22 Sekolah Dasar dari 5 kecamatan terpilih se-Kota Bengkulu, dimana pemilihan kecamatan serta sekolah dasar tujuan penelitian ditentukan langsung oleh Dinas Pendidikan Kota Bengkulu. Dan dari 22 sekolah dasar yang dilakukan penelitian, hanya 14 sekolah dasar saja yang benar-benar menyanggupi untuk mengisi lembaran survei dengan baik. 


\section{Subyek Penelitian}

Sampel terdiri atas 28 orang guru SD dari tiap sekolah yang telah ditentukan oleh Dinas Pendidikan Kota Bengkulu. Responden berusia rata-rata 36 - 56 tahun, dengan usia rata-rata 48,43 $(\mathrm{SD}=5,36)$. Dengan aktivitas pengalaman mengajar di sekolah dasar antara 12 sampai 36 tahun, rata-rata $27,53(S D=5,68)$. Dan semua responden adalah guru perempuan, ini menandakan bahwa guru perempuan masih mendominasi pada profesi guru di sekolah dasar khususnya untuk matapelajaran IPA. Berikut adalah bagan presentase perbandingannya antara usia, lama mengajar, dan jenis kelamin:

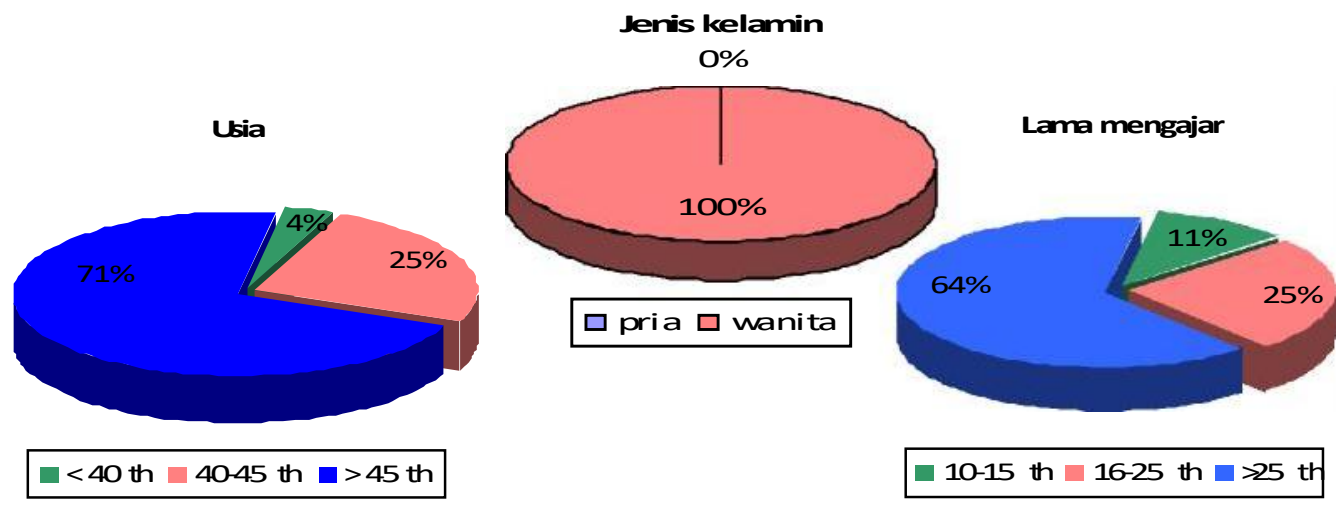

Gambar 1. Proporsi Responden Berdasarkan Karakteristik Usia, Lama Mengajar, dan Jenis Kelamin

\section{Pengumpulan Data}

Responden yang terdiri dari guru-guru SD diminta untuk melengkapi suatu survey (daftar pertanyaan). Instrumen penelitian ini diadopsi dari Volante \& Fazio (2007), terdiri atas serangkaian pertanyaan terbuka dan tertutup, yang berkisar pada: menggambarkan sendiri tingkatan literasi asesmen yang dimilikinya, tujuan utama dari asesmen, pemanfaatan berbagai teknik asesmen dan kebutuhan akan pelatihan lanjutan, serta usulan mengenai cara untuk meningkatkan pemahaman asesmen mahasiswa di perguruan tinggi (LPTK) dan pada kegiatan praktek mengajar (PPL). Secara keseluruhan, menurut Volante \& Fazio keempat hal pokok tersebut dapat menggambarkan literasi asesmen para guru yang menjadi responden penelitian ini.

\section{Analisa Data}

Pertanyaan survey meliputi empat pertanyaan tertutup dan lima pertanyaan terbuka (lihat Lampiran 1). Nilai rata-rata dan simpangan baku (SD) dari jawaban atas pertanyaan tertutup dihitung. Pertanyaan yang berkenaan dengan teknik asesmen yang sering digunakan dan tenik asesmen yang dibutuhkan dalam pelatihan di masa yang akan datang, terlebih dahulu dirata-ratakan skornya, kemudian dianalisis secara deskriptif. Dan jawaban responden atas pertanyaan-pertanyaan terbuka dianalisis langsung dengan statistik deskriptif.

\section{HASIL DAN PEMBAHASAN}

Hasil penelitian ini dititikberatkan pada beberapa pokok pembahasan, antara lain: literasi asesmen yang meliputi tujuan dan upaya peningkatan asesmen, pemanfaatan teknik-teknik asesmen, keberlanjutan dalam melatih penerapan teknik-teknik asesmen, serta saran yang terkait dengan perkuliahan di FKIP atau LPTK dalam upaya meningkatkan literasi asesmen. 
1. Literasi Asesmen : Tingkat Literasi dan Tujuan Asesmen

Berdasarkan hasil survei literasi asesmen, responden menilai kemampuan literasi asesmen mereka bervariasi. Tidak jauh berbeda dengan hasil penelitian sebelumnya (Akbar \& Rustaman, 2009), pada penelitian kali ini lamanya pengalaman mengajar mereka juga menentukan tingkat literasi asesmen mereka.

Berikut hasil survei level literasi asesmen responden yang berdasarkan pengalaman mengajar:

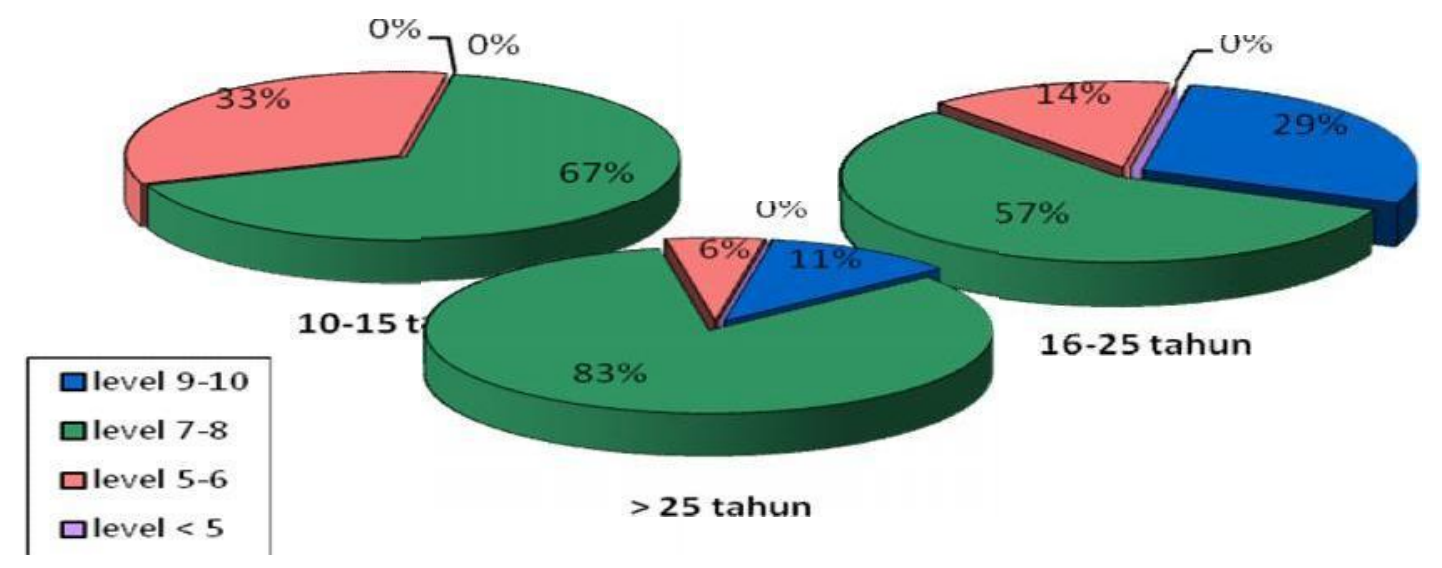

Gambar 2. Tingkat Literasi Asesmen Responden

Berdasarkan Lama Pengalaman Mengajar

Dilihat dari bagan hasil survei di atas (Gambar 2), sebagian besar responden dari pengalaman mengajar yang berbeda memiliki level literasi yang baik, yaitu berada di level 7-8. Dengan demikian, tampak jelas bahwa pengalaman mengajar memiliki pengaruh terhadap tingkat literasi asesmen responden (guru).

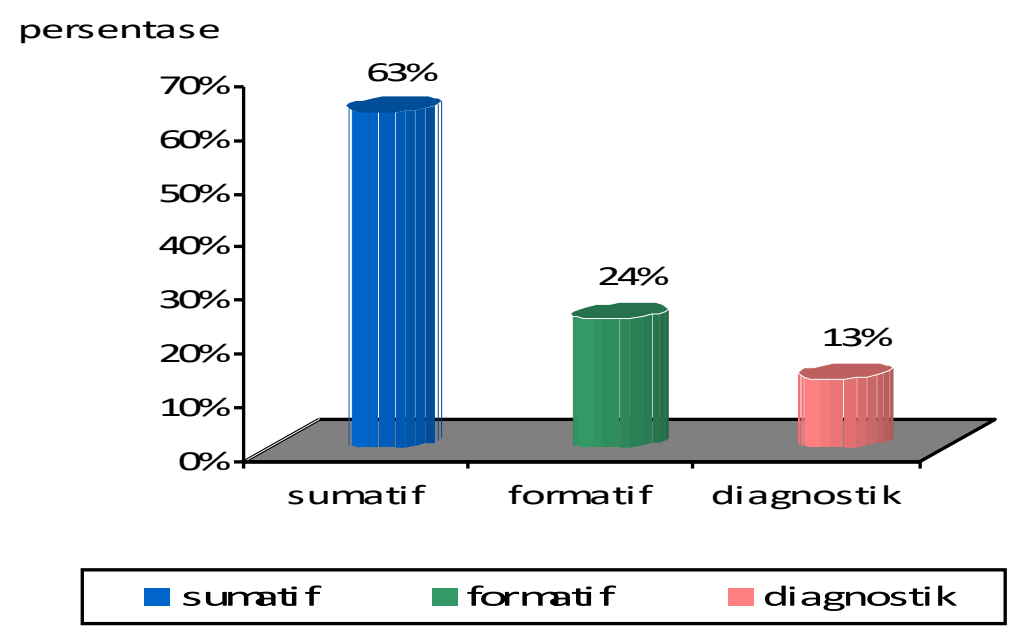

Gambar 3. Jawaban Responden Tentang Tujuan Asesmen di Kelas

Sementara itu, analisis terhadap jawaban survei atas pertanyaan mengenai tujuan utama dari asesmen, sebagian besar responden (63\%) masih menggunakan penilaian untuk tujuan sumatif dan formatif (24\%). Dan penggunaan asesmen untuk tujuan diagnostik masih jarang digunakan (13\%) seperti tampak pada Gambar 3. 
Adapun jawaban dari para responden ketika diberikan pertanyaan "Cantumkan tiga tujuan utama asesmen (penilaian) di kelas", jawaban yang paling dominan antara lain:

- untuk mengukur kemajuan dan hasil belajar

- untuk mengukur proses pembelajaran dan pengelolaan kelas

- untuk mengukur tingkat pemahaman dan ketuntasan belajar

- untuk menilai kemajuan dan hasil belajar siswa

- sebagai umpan-balik bagi guru terhadap KBM

Gambar 4. Jawaban Jawaban Survey Guru, 2010

Sementara itu, jawaban responden yang jarang muncul adalah (Jawaban Jawaban Survey Guru, 2010) :

- untuk mengevaluasi kompetisi peserta didik

- untuk mendiagnosis kelebihan dan kelemahan peserta didik

- untuk mengetahui pola pikir anak didik

- untuk meningkatkan motivasi belajar siswa

Gambar 5. Jawaban Jawaban Survey Guru, 2010

Dengan demikian, dapat disimpulkan bahwa para guru masih berpandangan bahwa penilaian atau asesmen hanya untuk tujuan sumatif dan formatif saja, padahal menurut Volante \& Fazio (2007) saat ini lebih dibutuhkan asesmen atau penilaian yang berorientasi untuk pengembangan (assessment for learning) dan metakognisi (assessement as learning) guna meningkatkan kualitas pembelajaran di sekolah.

\section{Teknik-Teknik Asesmen: Pemanfaatan dan Latihan lanjutan}

Seperti yang tampak pada Gambar 4, komunikasi perseorangan menjadi teknik asesmen yang paling sering digunakan oleh responden, dengan nilai 8,32 . Selanjutnya diikuti oleh tes pilihan $(8,25)$, essay terstruktur $(7,96)$, observasi $(7,82)$, asesmen kinerja $(6,50)$. Sementara itu, portofolio tidak terlalu sering digunakan oleh para responden dan dinilai sebesar 5,78 .

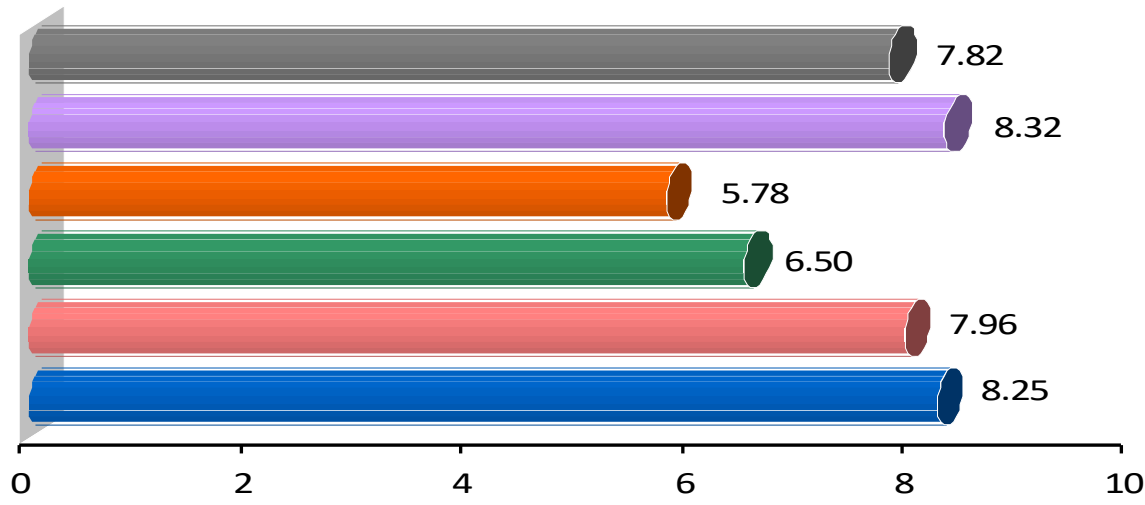

\begin{tabular}{|l|l|}
\hline tes pilihan & essayterstruktur \\
portofolio & komuni kasi perseorangan kinerja \\
\hline
\end{tabular}

Gambar 6. Teknik Asesmen Yang Paling Sering Digunakan

Jurnal Kesejahteraan Keluarga dan Pendidikan [JKKP] Vol.04 No.02 doi.org/10.21009/JKKP.042.09 
Alasan komunikasi personal menjadi pilihan responden antara lain sebagai berikut: mudah dilakukan, dapat mengukur tingkat kecerdasan dan pemahaman siswa secara langsung, serta dapat mengetahui sejauh mana masalah atau kesulitan siswa dalam menerima pelajaran. Namun demikian, melihat Gambar 6 di atas tampak bahwa tes pilihan masih dipilih oleh sebagian besar responden $(8,25)$, dengan alasan karena teknik asesmen bentuk tes pilihan mudah dilaksanakan dalam hal penilaian siswa, pengkoreksian, serta tes pilihan dinilai lebih objektif dalam menilai kemampuan siswa. (Jawaban Survey Guru, 2010).

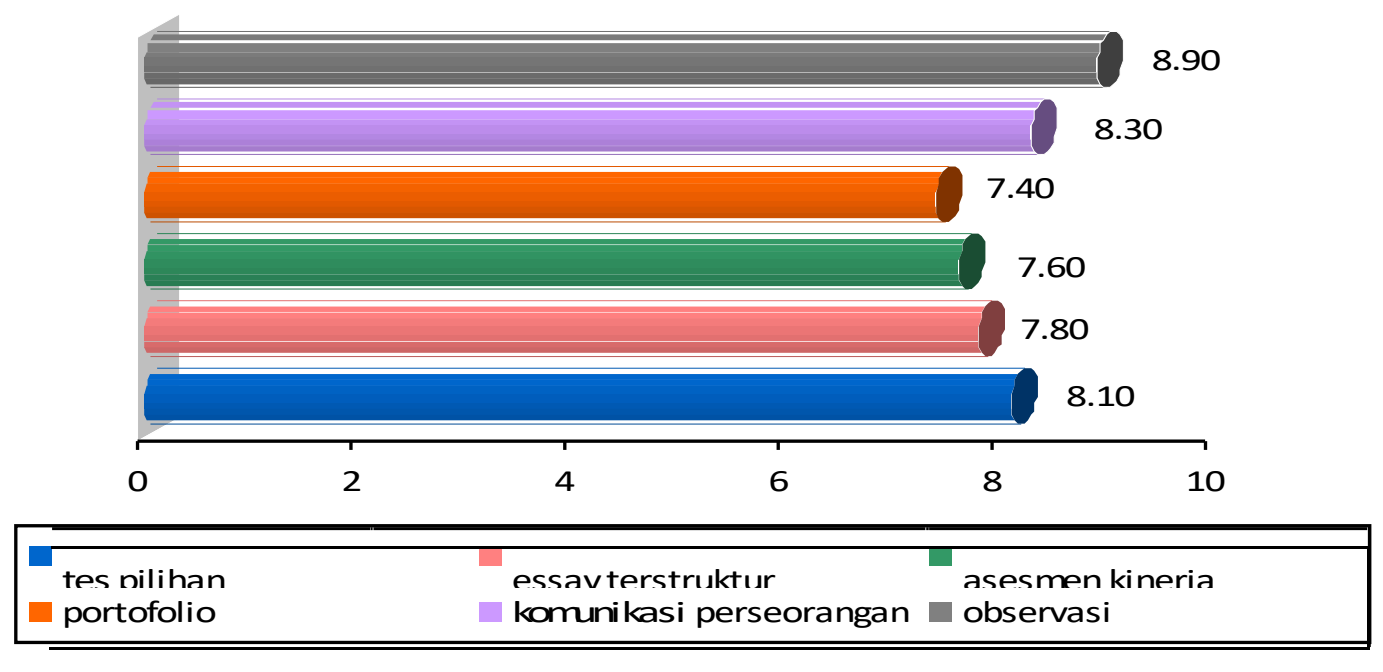

Gambar 7. Teknik Asesmen Yang Perlu Dilatihkan

Pada Gambar 7 menerangkan teknik asesmen yang perlu dilatihkan bila ada pelatihan teknik asesmen. Observasi menjadi teknik asesmen pilihan responden yang masih perlu dilatihkan $(8,90)$. Sesuai dengan konsep IPA (sains), bahwa IPA atau sains mengandung empat hal, yaitu: konten atau produk, proses atau metode, sikap dan teknologi (dalam Rustaman dkk, 2005), dan semua komponen IPA tersebut dapat dioptimalkan pembelajarannya dengan melakukan teknik observasi. Dengan demikian, guru pun sekiranya perlu melatihkan teknik asesmen observasinya agar kegiatan belajar mengajar khususnya dalam pembelajaran materi IPA atau sains menjadi lebih optimal.

\section{a. Pengembangan Literasi Asesmen}

Dalam hal ini, literasi asesmen didefinisikan sebagai pemahaman terhadap prinsip-prinsip asesmen. Berkaitan dengan hal tersebut penulis memberikan pertanyaan kepada responden yaitu "Sebutkan 3 cara/program yang membantu mengembangkan literasi asesmen Anda?". Beragam jawaban pun muncul dari pertanyaan tersebut, sehingga penulis mengkategorikan menjadi tiga cara/program, yakni studi lanjut ke S-1/S-2, mengikuti pelatihan khusus dan berupaya sendiri. Akan tetapi, dari ketiga jawaban tersebut, sebagian besar responden $(64,29 \%)$ menjawabnya dengan usulan jawaban yang kurang tepat atau menyimpang dari jawaban yang penulis kategorikan. Jawaban yang ditemukan seperti: membuat angket/RPP/metode belajar, melakukan pengamatan, skala sikap siswa, dan melihat latar belakang siswa. Dan hanya $10,71 \%$ saja yang paham akan hal tersebut, sehingga mereka memberikan jawaban yang mengarah pada berupaya sendiri. Jawaban itu antara lain: diskusi sesama guru di sekolah, melatih membuat kisi-kisi evaluasi, membuat program asesmen dan menganalisanya.

Hal tersebut dapat diartikan bahwa sebagian besar guru yang mengajar di daerah, masih belum memahami tentang prinsip-prinsip asesmen/penilaian yang dapat membantu pengembangan asesmen diri mereka sendiri, padahal kegiatan tersebut penting dalam upaya refleksi pembelajaran serta peningkatan kualitas belajar dan hasil belajar siswa. Dan tidak dapat dipungkiri bahwa 
minimnya fasilitas sarana dan prasarana serta kurangnya kemauan dari responden menjadi kendala dalam pengembangan literasi asesmen.

Terkait dengan perkuliahan di FKIP untuk meningkatkan literasi asesmen mahasiswa, guru memberikan usulan seperti:

- pembekalan materi perkuliahan kepada mahasiswa tentang prinsip-prinsip asesmen/penilaian dan strategi penilaian

- perbanyak praktek langsung menggunakan teknik-teknik asesmen dalam bentuk microteaching

- sering mengadakan diskusi kelompok dalam membahas dan melatih penggunaan teknik-teknik asesmen

Gambar 8. Jawaban Survey Guru, 2010

Dan terkait dengan kegiatan PPL (Program Pengalaman Lapangan), guru memberikan sarannya sebagai berikut:

- melatih diri dan menerapkan semua bentuk teknik asesmen dalam KBM di kelas

- lebih serius dalam mengajar dan objektif dalam penilaian kemampuan belajar siswa

- manfaatkan asesmen (penilaian) untuk mengenal karakteristik peserta didik

Gambar 9. Jawaban Survey Guru, 2010

\section{SIMPULAN}

Para guru Sekolah Dasar dari 5 Kecamatan terpilih antara lain kecamatan Gading Cempaka, Sungai Serut, Ratu Samban, Selebar, dan Ratu agung di wilayah Kota Bengkulu, yang menjadi responden penelitian ini menilai tingkat literasi asesmennya sangat baik. Faktor usia dan pengalaman mengajar menjadi pendukung tingginya tingkat literasi asesmen mereka.

Sebagian besar responden berpendapat asesmen dilakukan untuk tujuan sumatif, sedikit yang berpendapat asesmen dilakukan untuk keperluan formatif (pengembangan) dan diagnostik. Dan hal tersebut bertolakbelakang dengan pernyataan mereka terhadap nilai literasi asesmennya yang tinggi.

Responden memilih komunikasi personal sebagai teknik asesmen yang paling sering digunakan dalam pembelajaran, dan apabila ada pelatihan lanjutan tentang teknik penggunaan asesmen mereka lebih berharap mendapatkan materi teknik asesmen observasi. Hal ini berkaitan dengan konsep penilaian pembelajaran sains (IPA) di kelas.

Implikasi dari usulan mengenai pengembangan literasi asesmen di perguruan tinggi maupun di lapangan tempat para guru mengajar antara lain terjalinnya kerja sama antara dinas pendidikan dengan perguruan tinggi untuk membina kemampuan asesmen guru SD melalui berbagai bentuk pelatihan. Disamping itu, untuk level calon guru, LPTK diharapkan dapat membekali mahasiswa dengan materi perkuliahan yang diarahkan pada peningkatan literasi asesmen. 


\section{DAFTAR PUSTAKA}

Anonim. 2007. Paket Pelatihan. Asesmen dan Evaluasi. Tersedia: http://mbeproject.net/pelatihan36.pdf [11 Agustus 2010]

Akbar, B. \& Nuryani Y. Rustaman. 2009. Literasi Asesmen Guru Sekolah Dasar. Laporan Field Study tidak dipublikasikan. Universitas Pendidikan Indonesia. Bandung.

Depdiknas. 2006. Peraturan Menteri Pendidikan Nasional No. 22, 23, dan 24 Tahun 2006. Jakarta

Depdiknas. 2006. Undang-undang Republik Indonesia Nomor 14 tahun 2005 tentang Guru dan Dosen. Sinar Grafika. Jakarta.

Iskandar, S.M. dan Hidayat, E.M. 1997. Pendidikan IImu Pengetahuan Alam. Departemen Pendidikan dan Kebudayaan. Jakarta.

Puskur. 2007. Naskah Akademik Kajian Kebijakan Kurikulum Mata Pelajaran IPA. Balitbang Depdiknas. Jakarta.

Rustaman, N.Y. 2006. Literasi Sains Anak Indonesia 2000 dan 2003. Seminar Sehari Hasil Studi Internasional Prestasi Siswa Indonesia dalam Bidang Matematika, Sains,dan Membaca. Puspendik Depdiknas. Jakarta.

Rustaman, N.Y., Dirdjosoemarto, S., Adi-Yudianto, S., Achmad, Y. Subekti, R., Rochintaniawati, D. dan Nurjhani-K., M. 2005. Strategi Belajar Mengajar Biologi. Malang. UM.

Volante, L \& Fazio, X. 2007. Exploring teacher candidates' assessment literacy: Implications for teacher education reform and professional development. Can. J ournal of Education 30, 3 : 749-770. 